\title{
Dimethyl sulfoxide (DMSO) as the sulfur source for the production of desulfurizing resting cells of Gordonia alkanivorans RIPI90A
}

\section{Correspondence \\ Ghasemali Mohebali \\ mohebaligh@ripi.ir}

Received 8 September 2007

Revised 8 November 2007

Accepted 11 November 2007

\author{
Ghasemali Mohebali, ${ }^{1}$ Andrew S. Ball, ${ }^{2}$ Ashk Kaytash ${ }^{1}$ \\ and Behnam Rasekh ${ }^{1}$
}

${ }^{1}$ Department of Petroleum Biotechnology, Biotechnology Research Center, Research Institute of
Petroleum Industry, Tehran, Iran
${ }^{2}$ School of Biological Sciences, Flinders University of South Australia, Adelaide SA 5001, Australia

The sulfate repression of desulfurization (Dsz) phenotype represents a major barrier to the mass production of desulfurizing resting cells. This repression can be avoided by replacing sulfate with dibenzothiophene (DBT) as the main substrate for the 4S pathway. However, mass production of biocatalyst using DBT is impractical because of its high price, low water solubility, and growth inhibition by 2-hydroxybiphenyl (2-HBP), which is the end product of the $4 \mathrm{~S}$ pathway. In this work, the results showed that readily bioavailable sulfur compounds led to repression of the desulfurization activity of Gordonia alkanivorans RIPI90A. However, the Dsz phenotype was expressed through the 4S pathway in the presence of DMSO as the sulfur source for growth. Resting cells grown on DMSO were more active than the resting cells grown on DBT. The growth rate of strain RIPI90A on DMSO was higher than when DBT was used as the sole sulfur source. DMSO concentration significantly influenced the growth pattern of the strain, and the highest growth rate was observed at a concentration of $200 \mu \mathrm{g} \mathrm{ml}^{-1}$. Above this concentration, the growth rate gradually decreased. DBT was found to induce the Dsz phenotype, with no observed lag period, in cells grown on DMSO as the sole sulfur source. Prior to induction, the specific activity was detected as $1.4 \mu \mathrm{mol} 2-\mathrm{HBP}$ ( $\mathrm{g}$ dry cell weight $)^{-1} \mathrm{~h}^{-1}$, and following incubation $(5 \mathrm{~h}$ ) the highest specific activity was observed as $5.11 \mu \mathrm{mol} 2-\mathrm{HBP}$ ( $\mathrm{g}$ dry cell weight $)^{-1} \mathrm{~h}^{-1}$. This study identified that resting cells can be prepared in a two-step process. First, resting cells can be produced using DMSO as the sulfur source for growth; in the second step, improvements to their desulfurizing activity can be made using DBT as an inducer. DMSO is recommended as an appropriate sulfur source for the mass production of G. alkanivorans RIPI90A.

\section{INTRODUCTION}

Most of the sulfur found in crude oil is organically bound, mainly in the form of condensed thiophenes (Van Hamme et al., 2003). Research into the biocatalytic desulfurization (BDS) process, using dibenzothiophene (DBT) as a model compound, has resulted in the elucidation of two different biochemical desulfurization pathways, named the Kodama pathway (Kodama et al., 1973) and the 4S pathway (Denome et al., 1993; Oldfield et al., 1997; Piddington et al., 1995). Since the Kodama pathway is destructive, it is considered unsuitable as a basis for an industrial BDS process. Through the $4 \mathrm{~S}$ pathway, the carbon skeleton of DBT is released intact as 2-hydroxybiphenyl (2-HBP) (Fig. 1), so the value of the fuel is not lost. Various types of bacteria have been recognized to desulfurize DBT via the

Abbreviations: BDS, biocatalytic desulfurization; DBT, dibenzothiophene; $\mathrm{DBTO}_{2}$, dibenzothiophene sulfone; DCW, dry cell weight; DMF, dimethylformamide; 2-HBP, 2-hydroxybiphenyl.
4S pathway (McFarland, 1999). Among these strains, Gordonia alkanivorans RIPI90A has been found to be efficient at desulfurizing DBT via the $4 \mathrm{~S}$ pathway (Mohebali et al., 2007).

The $4 \mathrm{~S}$ pathway is a complex enzyme system, and its cofactors requirements prohibit the use of purified enzyme systems rather than whole cells for a practical BDS process (Kilbane \& Le Borgne, 2004). Therefore, for research into BDS, resting cells (i.e. non-proliferating cells) have been accepted as the best biocatalysts. Implementation of a commercial BDS process consists of several stages including: (i) growing the selected strain in a suitable medium in such a way as to obtain cells that exhibit the highest possible level of desulfurizing activity; and (ii) harvesting these active cells, and using them in the form of resting cells (biocatalysts) (Monot et al., 2002).

To make the BDS process economically competitive with the deep hydrodesulfurization process that is currently 
DBT

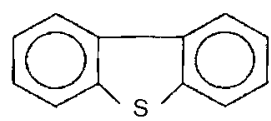<smiles>NC(=O)c1ccccc1C(N)=O</smiles>

DBT sulfoxide

$\mathrm{DszC} \mid \begin{aligned} & \mathrm{NADH} \\ & \mathrm{FMNH}_{2}\end{aligned}$ $\mathrm{O}_{2}$

DBT sulfone

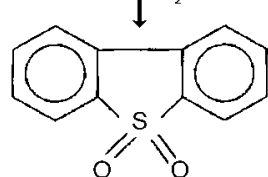

HPBS

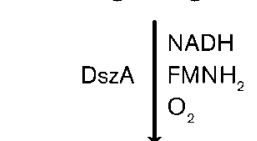

2-HBP

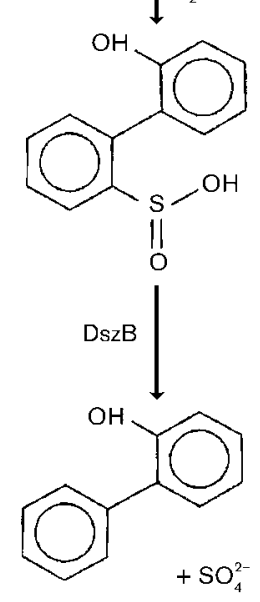

Fig. 1. The $4 S$ pathway for the biocatalytic desulfurization of DBT and its derivatives. HPBS, hydroxyphenyl benzene sulfonate; DszA, DBT sulfone monooxygenase; DszB, HPBS desulfinase; DszC, DBT monooxygenase.

used, it is necessary to improve several factors, including the cost of producing the biocatalyst, and its biocatalytic activity. It is well understood that the sulfur source used for growth strongly influences the desulfurization activity of resting cells (Li et al., 1996; Oldfield et al., 1997). In this context, sulfate contamination of the growth medium is one of the main barriers because desulfurization enzymes are sulfate-starvation-induced proteins (Tanaka et al., 2002), and the Dsz phenotype is repressed by readily bioavailable sulfur compounds, including sulfate (Kertesz, 2000; Li et al., 1996; Matsui et al., 2002; Ohshiro et al., 1996; Piddington et al., 1995; Wang \& Krawiec, 1996). There is no evidence of feedback inhibition of the $4 \mathrm{~S}$ pathway enzymes themselves, as the presence of sulfate in growth medium represses expression of desulfurization activity, but addition of sulfate to resting cells grown on DBT does not inhibit desulfurization activity (Guobin et al., 2006; Li et al., 1996; Wang \& Krawiec, 1996).

Due to the repression phenomenon, it is difficult to prepare cultures using inexpensive sulfate-containing media. The use of synthetic media with low sulfate content is an expensive option; therefore, several authors have reported attempts to overcome sulfate repression (Chang et al., 2001; Kishimoto et al., 2000; Matsui et al., 2002; Noda et al., 2003; Piddington et al., 1995; Tanaka et al., 2002). Our hypothesis is that the repression could be avoided by various microbiological means, including lowering the repressor (sulfate) content of the growth medium, and substitution of a sulfur source other than DBT for sulfate. Since low-sulfur-containing synthetic media are expensive, the first solution is not commercially attractive. Therefore, using an alternative sulfur source to DBT, with subsequent induction using DBT, represents a reasonable option. Therefore, the aims of this work were: (i) to investigate the effect of readily bioavailable sulfur sources, reported to be repressors of $d s z$ genes, on $G$. alkanivorans RIPI90A; (ii) to use an alternative sulfur source for growth, without any $d s z$ gene repression; and (iii) to determine the resting-cell preparation protocol under these new conditions.

\section{METHODS}

Chemicals and reagents. All chemicals were of analytical grade. DBT $(>95 \%)$ and DBT sulfone $\left(\mathrm{DBTO}_{2}\right)(97 \%)$ were purchased from Fluka and Aldrich, respectively. Dimethylformamide (DMF) (99\%) and ethyl acetate were purchased from Riedel-de Haën. Gibbs reagent (2,6-dicholoroquinone-4-chloroimide), methionine, cysteine and DMSO were obtained from Merck.

Micro-organism and media. G. alkanivorans RIPI90A was studied in this work. This strain was isolated from an enrichment programme, as a desulfurizing strain, as previously described (Mohebali et al., 2007).

Minimal salt medium (MS-medium) containing sodium benzoate as the sole carbon source was prepared (SB-MS medium), and used for cultivation of strain RIPI90A, as previously described (Mohebali et al., 2007). DMF was used as the co-solvent in which DBT was dissolved, and it was then added to the medium. Enriched nutrient broth (ENB) was prepared as previously described (Mohebali et al., 2007); this medium was solidified using agar $\left(15 \mathrm{~g}^{-1}\right.$; enriched nutrient agar, ENA), and used when necessary.

Gibbs assay. Gibbs reagent reacts with aromatic hydroxyl groups, such as 2-HBP, to form a blue-coloured complex (Kayser et al., 1993). Gibbs assay was used to detect and quantify 2-HBP produced by strain RIPI90A in SB-MS medium, as previously described (Mohebali et al., 2007). A standard curve was created using 2-HBP at various concentrations versus Gibbs assay results (data not shown); a linear correlation occurred at 2-HBP concentrations ranging between 0.1 and $12 \mathrm{mg}^{-1}$.

Analysis methods. All samples were centrifuged to remove cellular mass. Cell-free supernatants were analysed using HPLC and GC-MS, as previously described (Mohebali et al., 2007). 
Preparation of resting-cell suspension. Cells were grown in liquid SB-MS medium containing either DBT or DMSO as the sole sulfur source, and harvested in the late-exponential growth phase by centrifugation $(2880 \mathrm{~g}, 20 \mathrm{~min})$. It has been found previously that the highest specific activity, in terms of desulfurization, occurs in cells harvested from the late-exponential growth phase (Mohebali et al., 2007). A suspension of resting cells was prepared by resuspending the pellet in phosphate buffer $(0.1 \mathrm{M}, \mathrm{pH} 7.08)$, and adjusting the cell concentration $\left(\mathrm{OD}_{660}\right)$ to a suitable value.

Resting-cell reaction programme. Resting-cell suspensions ( $5 \mathrm{ml}$ ) were prepared as described above, and mixed with DBT $\left(300 \mu \mathrm{g} \mathrm{ml}^{-1}, 10 \%\right.$ solution in DMF). The reaction mixture was incubated at $30{ }^{\circ} \mathrm{C}$ on a rotary shaker $(120$ r.p.m.). Following incubation, the mixture was assessed using the Gibbs method, and extracted with ethyl acetate $(1: 1, \mathrm{v} / \mathrm{v})$ three times. Prior to the extraction, the $\mathrm{pH}$ of the mixture was adjusted to 2.0 using $\mathrm{HCl}$ $(4 \mathrm{M})$. The total volume of the extract was evaporated at room temperature to a volume of $250 \mu \mathrm{l}$, and the sample was analysed by HPLC for quantification of 2-HBP. The presence of 2-HBP was confirmed using GC-MS. In parallel, the test was performed using DBT-containing phosphate buffer as a control; this was prepared and treated in the same way as the reaction mixtures.

Effect of the readily bioavailable sulfur compounds on expression of the Dsz phenotype. In order to determine the effect of readily bioavailable sulfur compounds, including cysteine, methionine and sulfate, on expression of the Dsz phenotype, strain RIPI90A was grown in SB-MS medium containing $50 \mu \mathrm{g}$ DMSO $\mathrm{ml}^{-1}$, and supplemented with $150 \mu \mathrm{g} \mathrm{ml}^{-1}$ of each the sulfur compounds tested. Following incubation, cells in the late-exponential growth phase were harvested by centrifugation $(2880 \mathrm{~g}, 20 \mathrm{~min})$, and their desulfurization activity was measured using the resting-cell reaction, as described above. Following incubation $(3 \mathrm{~h})$, all reaction mixtures were assessed using the Gibbs method.

Effect of sulfate on the DBT-desulfurizing activity of strain RIPI90A. In order to study the effect of sulfate on the DBTdesulfurizing activity of $G$. alkanivorans, three flasks containing SBMS medium were inoculated with strain RIPI90A. DBT $\left(50 \mu \mathrm{g} \mathrm{ml}^{-1}\right)$, sulfate $\left(19.2 \mu \mathrm{g} \mathrm{ml}^{-1}\right)$ or DBT together with sulfate $\left(50 \mu \mathrm{g} \mathrm{ml}^{-1}\right.$ and $19.2 \mu \mathrm{g} \mathrm{ml}^{-1}$, respectively) was added to the flasks. The flasks containing DBT or sulfate alone were used as the controls. The flasks were incubated at $30{ }^{\circ} \mathrm{C}$ on a rotary shaker (120 r.p.m.) until lateexponential growth phase. When the cell concentrations $\left(\mathrm{OD}_{660}\right)$ of three flasks reached about 1.8, the cells were harvested, and used to prepare resting-cell suspensions $\left(\mathrm{OD}_{660} 10\right)$, and to perform the resting-cell reaction, as described above. Following incubation $(12 \mathrm{~h})$, samples were extracted, and analysed by HPLC for quantification of 2 -HBP, as described above. The presence of $2-\mathrm{HBP}$ was confirmed by GC-MS.

Effect of sulfate concentrations on expression of the Dsz phenotype during growth of strain RIPI90A. This strain was grown in SB-MS medium supplemented with $50 \mu \mathrm{g} \mathrm{DMSO} \mathrm{ml}{ }^{-1}$ as the sulfur source, and increasing amounts of sulfate $\left(0-9.6 \mu \mathrm{g} \mathrm{ml}^{-1}\right.$ in $1.9 \mu \mathrm{g} \mathrm{ml}^{-1}$ increments, and $9.6-38.4 \mu \mathrm{g} \mathrm{ml}^{-1}$ in $4.75 \mu \mathrm{g} \mathrm{ml}^{-1}$ increments). Following incubation $\left(\mathrm{OD}_{660} 1.34-1.67\right)$, the desulfurization activity of each culture was determined using the resting-cell reaction, as described above. Replicates of the reaction mixtures were assessed using the Gibbs method.

Effect of DMSO as the growth sulfur source on expression of the Dsz phenotype in strain RIPI90A. In order to study the effect of DMSO on expression of the Dsz phenotype, cells of strain RIPI90A were inoculated in SB-MS medium supplemented with $50 \mu \mathrm{g}$ DMSO $\mathrm{ml}^{-1}$, and incubated at $30{ }^{\circ} \mathrm{C}$ on a rotary shaker (120 r.p.m.). In late-exponential growth phase, cells were harvested, and used to prepare resting-cell suspensions $\left(\mathrm{OD}_{660} 10\right)$, as described above. Two resting-cell suspensions were used to study the ability of the cells to convert DBT and $\mathrm{DBTO}_{2}$ to 2 -HBP. DBT or $\mathrm{DBTO}_{2}\left(300 \mu \mathrm{g} \mathrm{ml}^{-1}\right.$, $10 \%$ solution in DMF) was added to each resting-cell suspension. The reaction mixtures were used to perform the resting-cell reaction, as described above. Following incubation $(12 \mathrm{~h})$, replicate reaction mixtures were extracted, and analysed by HPLC for quantification of $2-\mathrm{HBP}$, as described above. The presence of $2-\mathrm{HBP}$ was confirmed by GC-MS.

Growth of strain RIPI90A on DBT or DMSO. The aim of this part of the study was to compare the growth rate of strain RIPI90A when grown on DBT or DMSO as the sole sulfur source. The strain was inoculated in SB-MS medium supplemented with either DBT $\left(50 \mu \mathrm{g} \mathrm{ml}^{-1}\right)$ or DMSO $\left(50 \mu \mathrm{g} \mathrm{ml}^{-1}\right)$ as the sole sulfur source. Samples were taken regularly at a defined time interval $(4 \mathrm{~h})$, and growth was assessed $\left(\mathrm{OD}_{660}\right)$. Each sample was streaked on ENA to check for purity. A linear regression slope of a plot of $\log _{10} \mathrm{~g}$ dry cell weight (DCW) $1^{-1}$ versus time was used to calculate the growth rate $\left(h^{-1}\right)$.

Desulfurization activity of resting cells grown on DBT or DMSO. DBT desulfurization activity of resting cells grown on DBT or DMSO was studied as follows: resting-cell suspensions $\left(\mathrm{OD}_{660} 10\right)$ were prepared, and used to perform the resting-cell reaction using DBT, as described above. Following incubation ( $12 \mathrm{~h}$ ), the reaction mixtures were assessed by the Gibbs method, extracted with ethyl acetate, and analysed by HPLC for quantification of 2 -HBP, as described above. The presence of 2-HBP was confirmed using GC-MS.

Effect of DMSO on the DBT-desulfurizing activity of strain RIPI90A. In order to study the effect of DMSO on Dsz expression in the presence of DBT, cells of strain RIPI90A were inoculated into flasks containing SB-MS medium supplemented with a mixture of DBT $\left(50 \mu \mathrm{g} \mathrm{ml}^{-1}\right)$ and DMSO $\left(50 \mu \mathrm{g} \mathrm{ml}^{-1}\right)$ as the sulfur source for growth. In parallel, the strain was inoculated into two flasks containing the same medium supplemented with DMSO $\left(50 \mu \mathrm{g} \mathrm{ml}^{-1}\right)$ or DBT $\left(50 \mu \mathrm{g} \mathrm{ml}^{-1}\right)$ as the sulfur source for growth. These two flasks were used as controls. All flasks were incubated at $30{ }^{\circ} \mathrm{C}$ on a rotary shaker (120 r.p.m.). In late-exponential growth phase $\left(\mathrm{OD}_{660} 1.8\right)$, cells were harvested, and used to prepare restingcell suspensions $\left(\mathrm{OD}_{660} 10\right)$, which were used to perform the restingcell reaction, as described above. Following incubation (12 h), replicate samples were extracted, and analysed using HPLC for quantification of 2-HBP, as described above. The presence of 2-HBP was confirmed using GC-MS.

Dsz activity of resting cells grown on DMSO and sulfate together. In order to study the effect of DMSO on expression of the Dsz phenotype in the presence of sulfate, cells of strain RIPI90A were inoculated into a flask containing SB-MS medium supplemented with a mixture of DMSO $\left(15.6 \mu \mathrm{g} \mathrm{ml}^{-1}\right)$ and sulfate $\left(19.2 \mu \mathrm{g} \mathrm{ml}^{-1}\right)$ as the sulfur sources for growth. In parallel, the strain was inoculated into two flasks containing the same medium supplemented with DMSO $\left(15.6 \mu \mathrm{g} \mathrm{ml}^{-1}\right)$ or sulfate $\left(19.2 \mu \mathrm{g} \mathrm{ml}^{-1}\right)$ as the sulfur source for growth. All flasks were then incubated at $30{ }^{\circ} \mathrm{C}$ on a rotary shaker (120 r.p.m.). In the late-exponential growth phase $\left(\mathrm{OD}_{660} 1.8-1.9\right)$, cells were harvested, and used to prepare resting-cell suspensions $\left(\mathrm{OD}_{660} 10\right)$, which were used to perform the resting-cell reaction, as described above. Following incubation $(12 \mathrm{~h})$, the replicate reaction mixtures were extracted, and analysed by HPLC for quantification of $2-\mathrm{HBP}$, as described above. The presence of $2-\mathrm{HBP}$ was confirmed by GC-MS.

Induction of the Dsz phenotype in cells grown on DMSO or sulfate. To study the induction effect of DBT on desulfurization 
activity of cells grown on sulfate or DMSO as the sole sulfur source, cells were grown in SB-MS medium containing DMSO $\left(50 \mu \mathrm{g} \mathrm{ml}^{-1}\right)$ as the sole sulfur source, and also in sulfate-rich SB-MS medium (sulfate, $20 \mu \mathrm{g} \mathrm{ml}^{-1}$ ), on a rotary shaker $\left(120\right.$ r.p.m.) at $30{ }^{\circ} \mathrm{C}$, and harvested in late-exponential growth phase (DMSO, $\mathrm{OD}_{660} 1.717$; sulfate, $\left.\mathrm{OD}_{660} 1.755\right)$ using centrifugation $(2880 \mathrm{~g}, 20 \mathrm{~min})$. The resultant pellets were resuspended in MS medium containing ethanol $\left(1000 \mu \mathrm{g} \mathrm{ml}^{-1}\right)$ as the sole carbon source, at a cell concentration $\left(\mathrm{OD}_{660}\right)$ of 20 . To start the induction period, DBT $\left(300 \mu \mathrm{g} \mathrm{ml}{ }^{-1}\right.$, $10 \%$ solution in DMF) was added to the suspensions, and the reaction mixtures were then incubated at $30{ }^{\circ} \mathrm{C}$ on a rotary shaker (120 r.p.m.) for $12 \mathrm{~h}$. Every hour, an aliquot $(5 \mathrm{ml})$ of the mixture was withdrawn, centrifuged $(4500 \mathrm{~g}, 10 \mathrm{~min})$, and resuspended in phosphate buffer $(0.1 \mathrm{M}, \mathrm{pH} 7.08)$ to prepare the same cell concentration $\left(\mathrm{OD}_{660}\right.$ 20). Following the addition of DBT $\left(300 \mu \mathrm{g} \mathrm{ml}^{-1}, 10 \%\right.$ solution in DMF), the reaction mixture was incubated under the same conditions for $1 \mathrm{~h}$, and then assessed using the Gibbs method, extracted with ethyl acetate, and analysed by HPLC for quantification of 2-HBP, as described above. In parallel with Gibbs assay, UV radiation $(254 \mathrm{~nm})$ was used to confirm the results (Krawiec, 1990). Tests were carried out using duplicate samples.

\section{RESULTS}

\section{Effect of the readily bioavailable sulfur compounds on expression of the Dsz phenotype}

In this study, strain RIPI90A was grown on DMSO as the sulfur source for growth in the presence of sulfurcontaining amino acids (cysteine and methionine). Following the resting-cell reaction programme using DBT, Gibbs assessment of the resting-cell samples revealed that in the presence of these amino acids desulfurizing activity did not occur; both methionine and cysteine repressed desulfurization activity in $G$. alkanivorans RIPI90A.

Strain RIPI90A was also grown on a combination of DBT and sulfate as the sulfur sources for growth. In parallel, the strain was cultivated on either DBT or sulfate as the sulfur source. Following the resting-cell reaction programme using DBT, HPLC analysis of the reaction mixtures revealed that the 2-HBP accumulated in the reaction mixtures containing resting cells grown on sulfate or DBT plus sulfate at trace levels; however, for DBT, the concentration of 2 -HBP was $5 \mu \mathrm{g} \mathrm{ml}^{-1}$. This indicated that growing cells of the strain were unable to convert DBT to $2-\mathrm{HBP}$ in the presence of sulfate $\left(19.2 \mu \mathrm{g} \mathrm{ml}^{-1}\right)$.

\section{Effect of sulfate concentrations on expression of the Dsz phenotype during growth of strain RIPI90A on DMSO}

Cells of strain RIPI90A were grown on DMSO as the sulfur source, together with increasing amounts of sulfate. Following incubation, desulfurizing activity of cultures was determined using the resting-cell reaction. Gibbs assay results revealed that sulfate concentrations $\geqslant 14.4 \mu \mathrm{g} \mathrm{ml}^{-1}$ repressed the Dsz phenotype (data not shown).

\section{Effect of DMSO as the growth sulfur source on desulfurization pathway}

In order to study the effect of DMSO as the sole sulfur source on the $4 \mathrm{~S}$ pathway, resting cells grown on DMSO were reacted with DBT and $\mathrm{DBTO}_{2}$ separately. HPLC analysis of resting-cell reactions with DBT and $\mathrm{DBTO}_{2}$ (an intermediate of the $4 \mathrm{~S}$ pathway) showed 2-HBP concentrations of 1.63 and $5.10 \mu \mathrm{g} 2-\mathrm{HBP} \mathrm{ml}{ }^{-1}$, respectively. GCMS analysis confirmed the presence of $2-\mathrm{HBP}$ in all samples, indicating that the Dsz phenotype in $G$. alkanivorans RIPI90A could be expressed in the presence of DMSO as the sole sulfur source through the $4 \mathrm{~S}$ pathway.

\section{The growth of strain RIPI90A on DBT or DMSO}

Fig. 2(a) shows the growth patterns of strain RIPI90A on DBT and DMSO; the maximum cell concentration on DBT was achieved after incubation for $44 \mathrm{~h}$, while, on DMSO, the maximum cell concentration was observed after $36 \mathrm{~h}$. The growth rate of strain RIPI90A was higher on DMSO $\left(0.1172 \mathrm{~h}^{-1}\right)$ than when DBT $\left(0.1009 \mathrm{~h}^{-1}\right)$ was used as the sole sulfur source (Fig. 2b).

\section{Desulfurization activity of resting cells grown on DBT or DMSO}

Resting cells of strain RIPI90A grown on DMSO or DBT as the growth sulfur source were able to desulfurize DBT. HPLC analysis revealed that 2-HBP accumulated in the reaction mixtures at levels of $11.4 \mu \mathrm{g} \mathrm{ml}^{-1}$ for DMSO, and $3.2 \mu \mathrm{g} \mathrm{ml}^{-1}$ for DBT. Maximum specific activity of resting cells grown on DMSO and DBT were 3.46 and $0.97 \mu \mathrm{mol}$ 2-HBP $(\mathrm{g} \mathrm{DCW})^{-1} \mathrm{~h}^{-1}$, respectively. It was evident that DMSO was a more efficient sulfur substrate than DBT.

\section{Effect of DMSO on DBT-desulfurizing activity of strain RIPI90A}

In order to study the effect of DMSO on expression of the Dsz phenotype in the presence of DBT, strain RIPI90A was cultured on a mixture of DBT and DMSO. In parallel, the strain was grown with DBT or DMSO as the sulfur source. Following resting-cell reactions using DBT, HPLC analysis of the samples revealed that 2-HBP concentrations produced by resting cells grown on DMSO, DBT, or DBT plus DMSO, were $11.42,3.15$ and $1.63 \mu \mathrm{g} \mathrm{ml}^{-1}$, respectively, indicating that combinations of DMSO and DBT produced a decrease in expression of the Dsz phenotype.

\section{Effect of DMSO concentrations on the growth rate of strain RIPI90A}

Fig. 3 shows the linear regression slope of a plot of $\log _{10}(\mathrm{~g}$ DCW $~^{-1}$ ) against time for each concentration of DMSO used. The growth rates $\left(\mathrm{h}^{-1}\right)$ were calculated as 0.0449 , $0.1017,0.0431$ and 0.0349 for $100,200,300$ and $400 \mu \mathrm{g}$ DMSO $\mathrm{ml}^{-1}$, respectively. To measure the dispersion of 

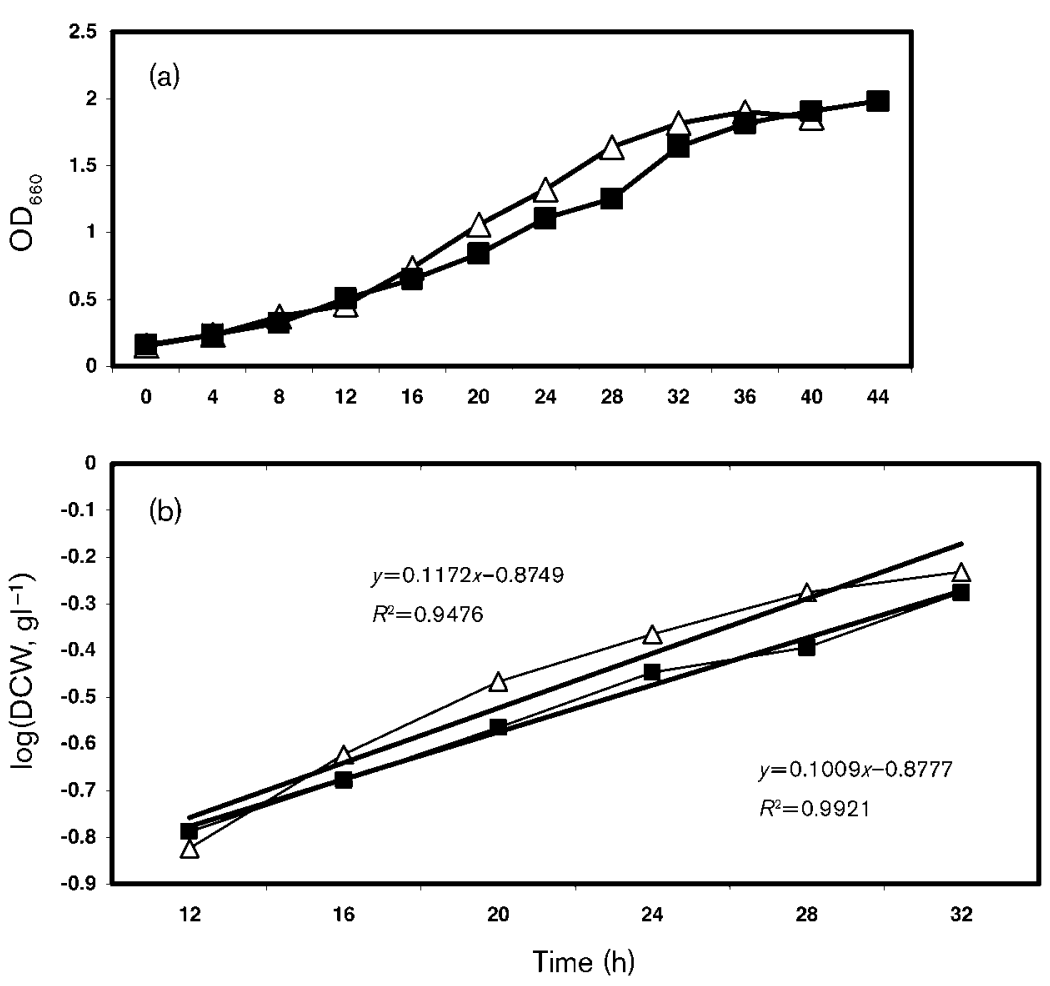

Fig. 2. The growth pattern of $G$. alkanivorans RIPI90A on DBT and DMSO as the growth sulfur source. (a) Growth curve; (b) comparison of the growth rates; $\triangle$, DMSO; $\mathbf{\square}, \mathrm{DBT}$. The replicate values varied by not more than $7.8 \%$ about the mean. distribution, the coefficient of variation (CV) was calculated for all concentrations. The CVs for all points of the curves were calculated to be from 0.023 to $8.632 \%$. The influence of various concentrations of DMSO on the growth rate of strain RIPI90A is shown in Fig. 4. DMSO concentrations significantly influenced the growth pattern of the strain; at a concentration of $100 \mu \mathrm{g} \mathrm{ml} \mathrm{m}^{-1}$, relatively low growth rates occurred. The highest growth rate was at a concentration of $200 \mu \mathrm{g} \mathrm{ml}{ }^{-1}$. Above this concentration the growth rate gradually decreased.

\section{Induction of the Dsz phenotype in the cells grown on DMSO or sulfate}

As shown in Fig. 5 the induction of the Dsz phenotype varied in cells grown on DMSO or sulfate. DBT was capable of inducing the Dsz phenotype in cells grown on DMSO as the sole sulfur source with almost no lag period. Prior to induction, the specific activity was $1.4 \mu \mathrm{mol} 2$ HBP $(g \text { DCW })^{-1} \mathrm{~h}^{-1}$; the highest specific activity [5.11 $\mu \mathrm{mol}$ 2-HBP $(\mathrm{g} \text { DCW })^{-1} \mathrm{~h}^{-1}$ ] was achieved after incubation for $5 \mathrm{~h}$. When the cells were grown on sulfate as the sole sulfur source, DBT was able to induce the Dsz phenotype, but only after a lag period. Prior to induction, desulfurization activity was not detected. The highest activity (Gibbs assay result, $\mathrm{OD}_{610} 0.88$ ) was achieved after incubation for $6 \mathrm{~h}$. Since the level of induction of Dsz phenotype was lower than the detection limit of HPLC, the results of the Gibbs assay were used to show the desulfurization activity of the cells grown on sulfate.

\section{DISCUSSION}

Because of the repression of $d s z$ genes by inorganic sulfate, most researchers have used DBT as the sulfur compound for growth (Kishimoto et al., 2000; Yan et al., 2000; Yoshikawa et al., 2002). Mass production of biocatalyst using DBT has been considered to be commercially impractical because of its high price, low water solubility, and growth inhibition by 2-HBP (Guobin et al., 2006; Honda et al., 1998; Kilbane \& Le Borgne, 2004; Ohshiro et al., 1996; Wang et al., 2004; Yoshikawa et al., 2002). Therefore, some researchers have tried to find a suitable sulfur source alternative to DBT (Yoshikawa et al., 2002).

DMSO has also been reported as a sulfur substrate that does not repress desulfurization activity in Rhodococcus erythropolis IGTS8, and it is not a substrate for the DBTdesulfurizing enzymes (Li et al., 1996). Expression of DBTdesulfurizing activity in the presence of DMSO is due to the de-repression of the $d s z$ operon in the absence of more readily bioavailable sulfur sources (e.g. sulfide, sulfate, cysteine and methionine) (Li et al., 1996; Oldfield et al., 1997). DMSO has been employed as the sulfur source for growth by several researchers (Abbad-Andaloussi et al., 2003a, b; Bouchez-Naïtali et al., 2004; Del Olmo et al., 2005; Li et al., 1996; Luo et al., 2003; Ma et al., 2006; Matsui et al., 2002; Mohebali et al., 2007; Oldfield et al., 1997; Omori et al., 1992; Pienkos, 1999); however, to date, no detailed microbiological study about how this sulfur compound influences the BDS process as the sole sulfur source has been carried out. 

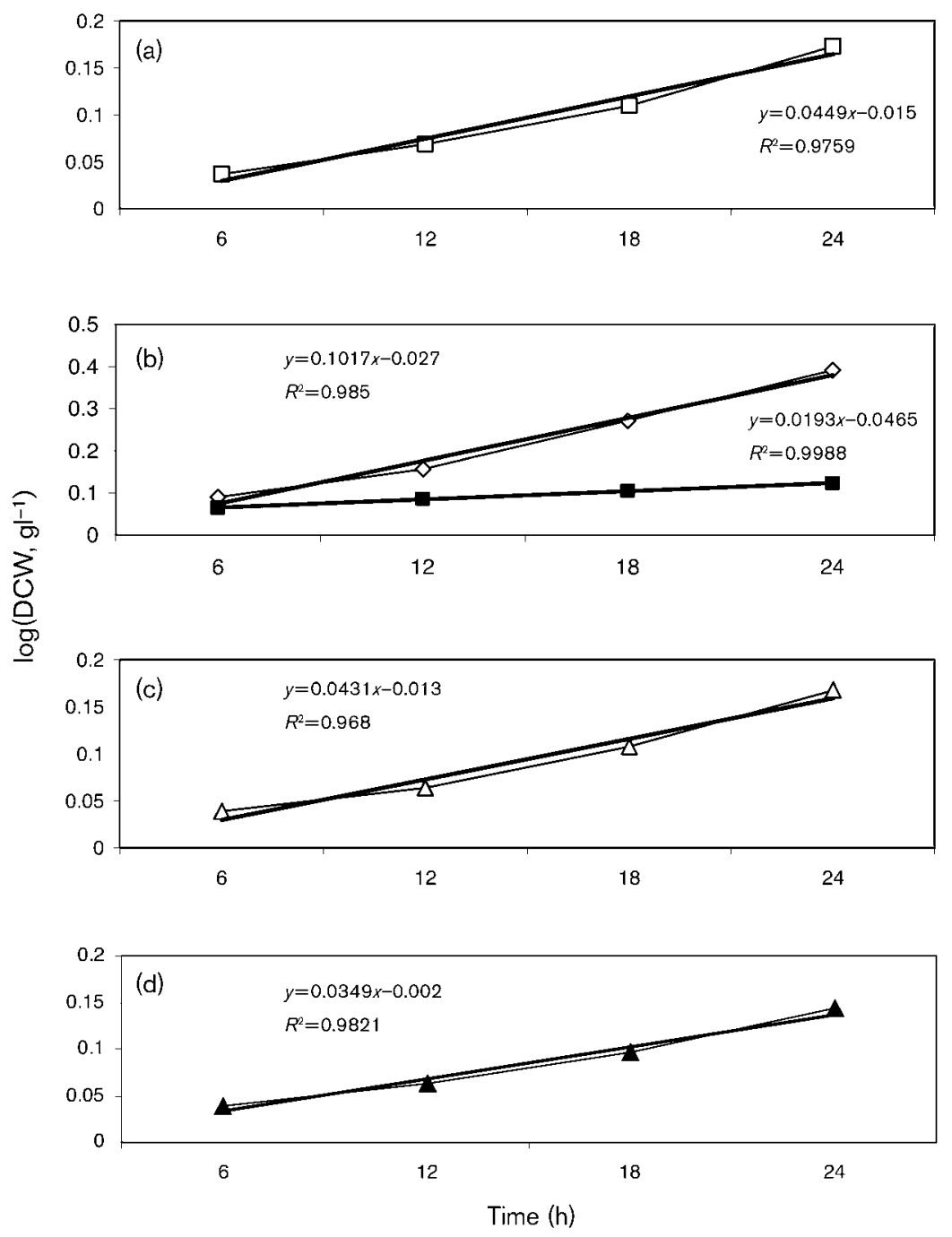

Fig. 3. The effect of various concentrations of DMSO on the growth rate of $G$. alkanivorans RIPI90A. Growth was carried out in medium containing various concentrations $\left(\mu \mathrm{g} \mathrm{ml}^{-1}\right)$ of DMSO: (a), 100; (b), $0(\diamond)$ and 200 (ם); (c), $300 ;(d), 400$.
G. alkanivorans RIPI90A has been found to be able to utilize DMSO as the sulfur source (Mohebali et al., 2007). RIPI90A resting cells grown on DMSO were reacted with DBT and $\mathrm{DBTO}_{2}$ separately, and the results revealed that the Dsz phenotype in this strain could be expressed via the $4 \mathrm{~S}$ pathway in the presence of DMSO as the sulfur source.

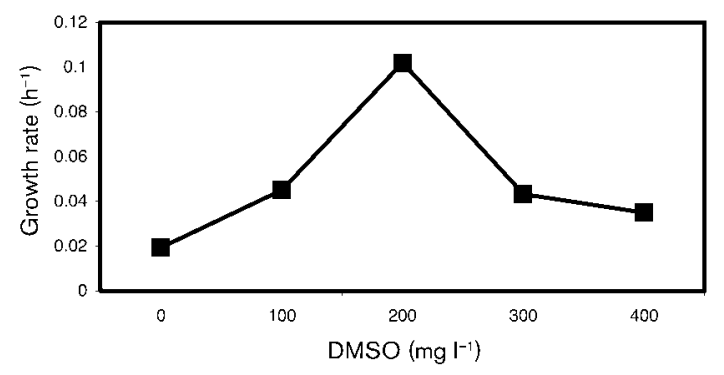

Fig. 4. Effect of various concentrations of DMSO on the growth rate $\left(\mathrm{h}^{-1}\right)$ of $\mathrm{G}$. alkanivorans RIPI90A.
DMSO has been found to be more easily metabolized than DBT, and it can also induce the $d s z$ genes (Bustos-Jaimes et al., 2003). However, with resting cells of Rhodococcus sp. lawq grown on DMSO as the sole sulfur source, desulfurization activity has been shown to be similar to that obtained with DBT (Ma et al., 2006). Resting cells of strain RIPI90A grown on DMSO or DBT as the sulfur source were able to desulfurize DBT. Resting cells grown on DMSO were more active than resting cells grown on DBT. The growth rate of strain RIPI90A on DMSO was higher than its growth rate on DBT. The results revealed that DMSO was more efficient as the sulfur source than DBT.

The effects of DMSO concentration on growth and Dsz activity of $R$. erythropolis KA2-5-1 have been investigated. It has been found that DMSO concentrations above $23.4 \mu \mathrm{g}$ $\mathrm{ml}^{-1}$ significantly decrease desulfurization activity and cell growth (Yoshikawa et al., 2002). Various concentrations of DMSO also influenced the growth pattern of strain RIPI90A: at $200 \mu \mathrm{g} \mathrm{ml} \mathrm{m}^{-1}$, DMSO was able to support 


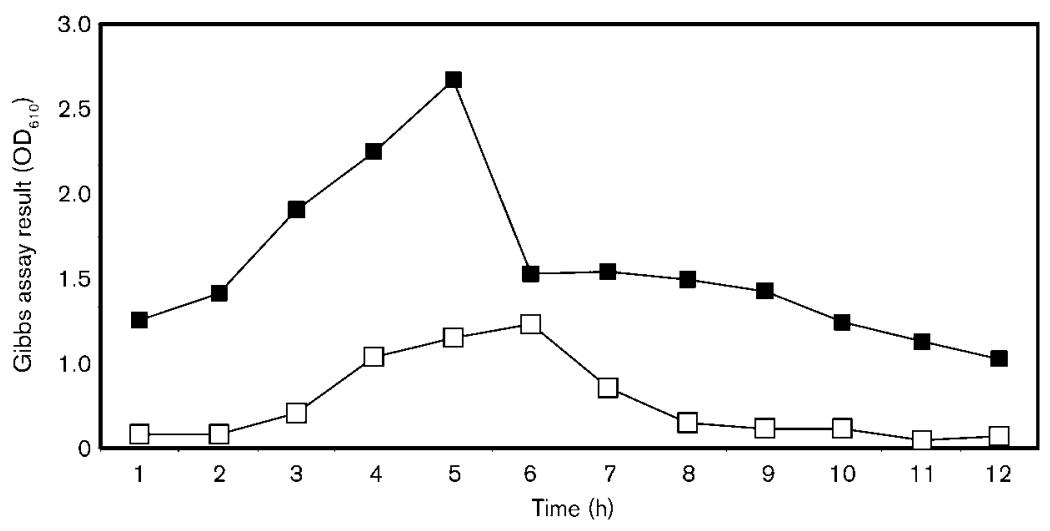

Fig. 5. Dsz phenotype induced by DBT in the cells grown on DMSO and sulfate. Gibbs assay results were used to show desulfurization activity of the cells of $G$. alkanivorans RIPI90A. - DMSO; $\square$, sulfate. The replicate values varied by not more than $6.1 \%$ about the mean.

maximum growth of strain RIPI90A; above this concentration, the growth rate gradually decreased; this suggests that DMSO may be toxic to the strain at concentrations above $200 \mu \mathrm{g} \mathrm{ml}^{-1}$.

It has been confirmed previously that DBT desulfurization by $G$. alkanivorans RIPI90A occurs via the 4 S pathway (Mohebali et al., 2007). It was necessary to study the repression of Dsz phenotype in strain RIPI90A by readily bioavailable sulfur compounds (sulfate, methionine and cysteine). The results revealed that these sulfur compounds could repress the desulfurization activity of strain RIPI90A. In the presence of DBT, sulfate could repress expression of $d s z$ genes in growing cells of strain RIPI90A. It was also concluded that DBT was not able to induce the Dsz phenotype. Studies on the effect of DMSO and various sulfate concentrations on expression of the Dsz phenotype revealed that, in the presence of DMSO and sulfate $\left(\geqslant 14.4 \mu \mathrm{g} \mathrm{ml}^{-1}\right)$, expression of the Dsz phenotype did not occur in growing cells of strain RIPI90A.

Following confirmation of DMSO as the most appropriate sulfur source for cultivation of active resting cells of strain RIPI90A, we aimed to establish a resting-cell production protocol. When DMSO is used as the sulfur source, cell growth is able to proceed in two steps: the first step involves growth at the expense of the unwanted sulfate content of the synthetic growth medium; during the second step, cell growth continues using DMSO as the growth sulfur source. Therefore, in the second step, expression of the Dsz phenotype can occur.

In an attempt to induce the Dsz phenotype in cells grown on sulfate as the sole sulfur source, several researchers have reported the use of a two-stage process. In their method, growth and Dsz-phenotype-induction stages have been performed separately: after acquiring a high-cell-density culture at the expense of sulfate, the Dsz phenotype was induced in the second stage using DBT (Chang et al., 2001; Honda et al., 1998; Ma et al., 2006). In the present work, the effects of DMSO together with DBT on $d s z$ gene expression were studied. The results showed that the presence of DMSO $\left(\geqslant 15.6 \mu \mathrm{g} \mathrm{ml}^{-1}\right)$ could interfere with DBT desulfurization. It was concluded that the induction stage must be performed separately. The induction of the Dsz phenotype by DBT occurred in cells grown on DMSO, with almost no lag period. The highest specific activity (about 3.6 times the activity at the start of the induction period) was achieved after incubation for $5 \mathrm{~h}$. After this period, a reduction in the specific activity took place (approx. $53 \%)$. This reduction was probably due to a decrease in desulfurization enzyme pool of the resting cells because of the presence of DBT as the main substrate for the $4 \mathrm{~S}$ pathway. DBT was found to induce the Dsz phenotype following an initial lag period in cells grown on sulfate as the sole sulfur source. Prior to induction, desulfurization activity was not detected. Therefore, DMSO was shown to be a much more potent substrate when compared with sulfate.

In conclusion the results of this investigation revealed that DMSO was more efficient as the sulfur source than DBT. This study confirms that active resting cells can be prepared in two steps as follows: (i) production of resting cells using DMSO as the sulfur source for growth, and (ii) improvement of their desulfurization activity by using DBT as an inducer. Therefore, DMSO is recommended as a sulfur source that is more appropriate than DBT for the mass production of $G$. alkanivorans RIPI90A.

\section{ACKNOWLEDGEMENTS}

The Iranian Research Institute of Petroleum Industry financed this research. We thank M. Shavandi and K. Faryadin for their contribution. Thanks also to S. V. Samimi and P. Soleimani for analyses using laboratory instruments.

\section{REFERENCES}

Abbad-Andaloussi, S., Lagnel, C., Warzywoda, M. \& Monot, F. (2003a). Multi-criteria comparison of resting cell activities of bacterial strains selected for biodesulfurization of petroleum compounds. Enzyme Microb Technol 32, 446-454.

Abbad-Andaloussi, S., Warzywoda, M. \& Monot, F. (2003b). Microbial desulfurization of diesel oils by selected bacterial strains. Oil Gas Sci Technol 58, 505-513.

Bouchez-Naïtali, M., Abbad-Andaloussi, S., Warzywoda, M. \& Monot, F. (2004). Relation between bacterial strain resistance to 
solvents and biodesulfurization activity in organic media. Appl Microbiol Biotechnol 65, 440-445.

Bustos-Jaimes, I., Amador, G., Castorena, G. \& Le Borgne, S. (2003). Genotypic characterization of sulfur-oxidative desulfurizing bacterial strains isolated from Mexican refineries. Oil Gas Sci Technol 58, 521-526.

Chang, J. H., Kim, Y. J., Lee, B. H., Cho, K.-S., Rye, H. W., Chang, Y. K. \& Chang, H. N. (2001). Production of a desulfurization biocatalyst by two-stage fermentation and its application for the treatment of model and diesel oils. Biotechnol Prog 17, 876-880.

Del Olmo, C. H., Alcon, A., Santos, V. E. \& Garcia-Ochoa, F. (2005). Modeling the production of a Rhodococcus erythropolis IGTS8 biocatalyst for DBT biodesulfurization: influence of media composition. Enzyme Microb Technol 37, 157-166.

Denome, S. A., Olson, E. S. \& Young, K. D. (1993). Identification and cloning of genes involved in specific desulfurization of dibenzothiophene by Rhodococcus sp. strain IGTS8. Appl Environ Microbiol 59, 2837-2843.

Guobin, S., Huaiying, Z., Jianmin, X., Guo, C., Wangliang, L. \& Huizhou, L. (2006). Biodesulfurization of hydrodesulfurized diesel oil with Pseudomonas delfieldii R-8 from high density culture. Biochem Eng J 27, 305-309.

Honda, H., Sugiyama, H., Saito, I. \& Kobayashi, T. (1998). High cell density culture of Rhodococcus rhodochrous by $\mathrm{pH}$-stat feeding and dibenzothiophene degradation. J Ferment Bioeng 85, 334-338.

Kayser, K. J., Bielaga-Jones, B. A., Jackowski, K., Odusan, O. \& Kilbane, J. J. (1993). Utilization of organosulfur compounds by axenic and mixed cultures of Rhodococcus rhodochrous IGTS8. J Gen Microbiol 139, 3123-3129.

Kertesz, M. A. (2000). Riding the sulfur cycle-metabolism of sulfonates and sulfate esters in Gram-negative bacteria. FEMS Microbiol Rev 24, 135-175.

Kilbane, J. J. \& Le Borgne, S. (2004). Petroleum biorefining: the selective removal of sulfur, nitrogen, and metals. In Petroleum Biotechnology, Developments and Perspectives, pp. 29-65. Edited by R. Vazquez-Duhalt \& R. Quintero-Ramirez. The Netherlands: Elsevier.

Kishimoto, M., Inui, M., Omasa, T., Katakura, Y., Suga, K. \& Okumura, K. (2000). Efficient production of desulfurizing cells with the aid of expert system. Biochem Eng J 5, 143-147.

Kodama, K., Umehara, K., Shimizu, K., Nakatani, S., Minoda, Y. \& Yamada, K. (1973). Identification of microbial products from dibenzothiophene and its proposed oxidation pathway. Agric Biol Chem 37, 45-50.

Krawiec, S. (1990). Bacterial desulfurization of thiophene: screening techniques and some speculations regarding the biochemical and genetic bases. Dev Ind Microbiol 31, 103-114.

Li, M. Z., Squires, C. H., Monticello, D. J. \& Childs, J. D. (1996). Genetic analysis of the $d s z$ promoter and associated regulatory regions of Rhodococcus erythropolis IGTS8. J Bacteriol 178, 6409-6418.

Luo, M., Xing, J., Gou, Z., Li, S., Liu, G., Xie, Y., Liu, H. \& Chen, J. (2003). Effects of different sulfur sources on growth and desulfurization activity of Nocardia globerula R-9. J Chem Ind Eng (China) 54, 1413-1417.

Ma, C. Q., Feng, J. H., Zeng, Y. Y., Cai, X. F., Sun, B. P., Zhang, Z. B., Blankespoor, H. D. \& Xu, P. (2006). Methods for the preparation of a biodesulfurization biocatalyst using Rhodococcus sp. Chemosphere 65, $165-169$
Matsui, T., Noda, K., Tanaka, Y., Maruhashi, K. \& Kurane, R. (2002). Recombinant Rhodococcus sp. strain T09 can desulfurize DBT in the presence of inorganic sulfate. Curr Microbiol 45, 240-244.

McFarland, B. L. (1999). Biodesulfurization. Curr Opin Microbiol 2, 257-264.

Mohebali, G., Ball, A. S., Rasekh, B. \& Kaytash, A. (2007). Biodesulfurization potential of a newly isolated bacterium, Gordonia alkanivorans RIPI90A. Enzyme Microb Technol 40, 578-584.

Monot, F., Abbad-Andaloussi, S. \& Warzywoda, M. (2002). Biological culture containing Rhodococcus erythropolis and/or Rhodococcus rhodnii and process for desulfurization of petroleum fraction. US Patent no. 6337204.

Noda, K., Watanabe, K. \& Maruhashi, K. (2003). Cloning of rhodococcus promoter using a transposon for dibenzothiophene biodesulfurization. Biotechnol Lett 25, 1875-1882.

Ohshiro, T., Suzuki, K. \& Izumi, Y. (1996). Regulation of dibenzothiophene degrading enzyme activity of Rhodococcus erythropolis D-1. J Ferment Bioeng 81, 121-124.

Oldfield, C., Pogrebinsky, O., Simmonds, J., Olson, E. S. \& Kulpa, C. F. (1997). Elucidation of the metabolic pathway for dibenzothiophene desulfurization by Rhodococcus sp. strain IGTS8 (ATCC 53968). Microbiology 143, 2961-2973.

Omori, T., Monna, L., Saiki, Y. \& Kodama, T. (1992). Desulfurization of dibenzothiophene by Corynebacterium sp. strain SY1. Appl Environ Microbiol 58, 911-915.

Piddington, C. S., Kovacevich, B. R. \& Rambosek, J. (1995). Sequence and molecular chacterization of a DNA region encoding the dibenzothiophene desulfurization operon of Rhodococcus sp. strain IGTS8. Appl Environ Microbiol 61, 468-475.

Pienkos, P. T. (1999). Choosing the best platform for the biotransformation of hydrophobic molecules. In Microbial Biosystems: New Frontiers. Proceedings of the 8th International Symposium on Microbial Ecology, pp. 875-888. Edited by C. R. Bell, M. Brylinsky \& P. JohnsonGreen. Halifax, Canada: Atlantic Canada Society for Microbial Ecology.

Tanaka, Y., Yoshikawa, O. \& Maruhashi, K. (2002). The $c b s$ mutant strain of Rhodococcus erythropolis KA2-5-1 expresses high levels of Dsz enzymes in the presence of sulfate. Arch Microbiol 178, 351-357.

Van Hamme, J. D., Singh, A. \& Ward, O. P. (2003). Recent advances in petroleum microbiology. Microbiol Mol Biol Rev 67, 503-549.

Wang, P. \& Krawiec, S. (1996). Kinetic analysis of desulfurization of dibenzothiophene by Rhodococcus erythropolis in batch and fed-batch cultures. Appl Environ Microbiol 62, 1670-1675.

Wang, M. D., Li, W., Wang, D. H. \& Shi, Y. (2004). Desulfurization of dibenzothiophene by a newly isolated Corynebacterium sp. ZD-1 in aqueous phase. J Environ Sci (China) 16, 1011-1015.

Yan, H., Kishimoto, M., Omasa, T., Katakura, Y., Suga, K., Okumura, K. \& Yoshikawa, O. (2000). Increase in desulfurization activity of Rhodococcus erythropolis KA2-5-1 using ethanol feeding. $J$ Biosci Bioeng 89, 361-366.

Yoshikawa, O., Ishii, Y., Koizumi, K., Ohshiro, T., Izumi, Y. \& Maruhashi, K. (2002). Enhancement and stabilization of desulfurization activity of Rhodococcus erythropolis KA2-5-1 by feeding ethanol and sulfur components. J Biosci Bioeng 94, 447-452.

Edited by: G. Muyzer 